\title{
Werkverslaving, een begrip gemeten
}

\author{
Wilmar Schaufeli, Corine van Wijhe, Maria Peeters \& Toon Taris
}

\begin{abstract}
Werkverslaving of workaholisme wordt opgevat als overmatig en dwangmatig werken. Gebaseerd op deze omschrijving wordt de DUWAS (Dutch Workaholism Scale) geïntroduceerd, een korte zelfbeoordelinglijst die bestaat uit twee gecorreleerde subschalen van ieder vijf items: excessief werken (EW) en compulsief werken (CW). Op basis van een nationale database $(n=11.060)$ zijn afkapwaarden berekend met behulp waarvan de mate van werkverslaving kan worden vastgesteld. Uit analyses $(n=1.166)$ blijkt dat met name de combinatie van hoge scores op zowel $\mathrm{EW}$ als $\mathrm{CW}$ ongunstig is. Geconcludeerd wordt dat de DUWAS een betrouwbaar en valide instrument is dat bijvoorbeeld kan worden ingezet als screeningsinstrument om werkverslaafden op te sporen.
\end{abstract}

\section{Inleiding}

Het is niet verbazingwekkend dat juist in het huidige tijdsgewricht, waarin de nadruk ligt op hard werken, presteren en excelleren, de aandacht voor werkverslaving lijkt toe te nemen. Ook het feit dat men tegenwoordig, dankzij de moderne informatie- en communicatietechnologie, bijna overal en altijd kan werken, draagt daar aan bij. Bovendien loont hard werken. Zo bleek uit een enquête onder 20.000 lezers van Intermediair dat diegenen die tenminste 50 uur per week werkten, na 15 jaar gemiddeld ruim 50\% méér verdienden dan diegenen die minder tijd aan hun werk besteedden (De Vos, 2003).

Alhoewel de term 'workaholisme' al ruim vier decennia geleden werd geïntroduceerd (Oates, 1968), duurde het tot de afgelopen eeuwwisseling voor er schot in het aantal wetenschappelijke publicaties over werkverslaving kwam. Zo telden Taris en Schaufeli (2007) tussen 2001 en 2006 in totaal 88 publicaties in PsycLIT, ongeveer evenveel als de 96 in de drie decennia daarvoor. Ter vergelijking: over burn-out zijn tussen 2001 en 20061.229 publicaties verschenen, ongeveer 14 keer zoveel dus. Er is geopperd dat dit relatief geringe aantal wetenschappelijke publicaties over workaholisme te maken heeft met het ontbreken van een algemeen geaccepteerde definitie en een daarop gebaseerd meetinstrument (McMillan \& O’Driscoll, 2006). In dit artikel proberen we hiertoe een aanzet te geven door, op basis van een definitie die gebaseerd is op de meest gebruikte omschrijvingen van workaholisme, een korte zelfbeoordelingvragenlijst te intro-

* Universiteit Utrecht, Arbeids- en Organisatiepsychologie 
duceren. Deze vragenlijst - de DUtch WorkAholism Scale (DUWAS) - is inmiddels door ruim 10.000 Nederlandse werknemers ingevuld. Het onderhavige artikel beschrijft de constructie en de psychometrische evaluatie van de DUWAS, alsmede de normering van deze vragenlijst.

\subsection{Het begrip workaholisme}

Workaholisme is een woord met een knipoog. De geestelijke vader van de term, de Amerikaanse dominee en psychologieprofessor Wayne E. Oates (1971, p. 13), beschouwde dit neologisme als een '... semihumorous word for addiction to work'. Zoals wel vaker voorkomt bij psychologen was hijzelf slachtoffer van het verschijnsel dat hij beschreef. Uiteraard waren er ook mensen verslaafd aan hun werk voordat de term workaholisme bekend werd. Een voorbeeld van zo'n workaholic avant la lettre is de Franse schrijver Gustave Flaubert die in 1852 in een brief aan zijn maîtresse schreef : 'I love my work with a frenetic and perverted love' (geciteerd in Unwin, 2004, p. 10). Echter, pas na de publicatie van Oates' bestseller in 1971 - met als titel Confessions of a workaholic - werd het verschijnsel wereldwijd bekend, eerst bij het grote publiek en daarna in de wetenschap.

Oates omschrijft workaholisme als '...the compulsion or the uncontrollable need to work incessantly' (1971, p. 11). Er zijn hier dus twee wezenlijke elementen in het geding - dwangmatig en onophoudelijk werken -, die respectievelijk als de cognitieve en de gedragsmatige component van workaholisme gezien kunnen worden. Veel tijd besteden aan het werk is weliswaar een noodzakelijke maar geen voldoende reden om van werkverslaving te spreken (Machlowitz, 1980). Immers, men kan ook hard werken om veel geld te verdienen, om carrière te maken, om een ongelukkig huwelijk te ontvluchten, of omdat de leidinggevende het wil en de collega's het ook doen. Daarmee is er nog geen sprake van een werkverslaving (Snir \& Zohar, 2006). Die komt pas om de hoek kijken wanneer dit harde werken voortvloeit uit een niet te onderdrukken innerlijke drang. Met andere woorden, wanneer werken tot een obsessie wordt. Werkverslaafden voelen zich nutteloos, schuldig, geïrriteerd en gespannen wanneer ze niet kunnen werken, maar eenmaal aan het werk verdwijnen deze onlustgevoelens grotendeels (Porter, 1996; Scott, Moore \& Miceli, 1997). Alhoewel er in de afgelopen drie decennia veel verschillende definities van workaholisme zijn verschenen loopt de oorspronkelijke omschrijving van Oates er als een rode draad doorheen. In een synthese van eerder onderzoek en theorievorming stellen Scott et al. (1997) dat in ieder geval aan twee eisen voldaan moet zijn om te kunnen spreken van werkverslaving. De eerste daarvan is dat werkverslaafden veel tijd besteden aan hun werk als zij daartoe de kans krijgen, hetgeen leidt tot verarming van hun sociale leven en verwaarlozing van allerlei andere (ontspannende) activiteiten. Werkverslaafden zijn dus excessief harde werkers. Het tweede element is dat werkverslaafden bijna altijd aan hun werk denken, dus ook buiten het werk in hun vrije tijd. Werkverslaafden zijn dus ook dwangmatige werkers.

Ook meer recente analyses van definities van workaholisme komen tot de conclusie dat excessief hard werken en een niet te stuiten innerlijke drang de kern uitmaken van werkverslaving (McMillan \& O’Driscoll, 2006; Ng, Sorensen \& Feldman, 2007). Dat onze bovenstaande definitie van workaholisme eveneens 
overeenkomt met de opvatting die leken daarover hebben, wordt geïllustreerd door het onderzoek van McMillan en O’Driscoll (2006). Zij vroegen werknemers, hun partners en hun collega's hoe zij een workaholic zouden beschrijven. $\mathrm{Na}$ inhoudsanalyse van de gegeven antwoorden bleken de volgende twee elementen het meest te zijn genoemd: 'de grote hoeveelheid tijd die aan werken en daaraan denken wordt besteed' (39\%) en 'een dwangmatige persoonlijkheidsstijl' (22\%).

De conclusie luidt dat de beide elementen die wij in navolging van Wayne E. Oates aan workaholisme onderscheiden - excessief hard werken en compulsief werken als kernelementen worden teruggevonden in de meeste andere academische definities, alsmede in de opvatting die leken hebben over werkverslaving.

\subsection{Het meten van werkverslaving}

Overeenkomstig onze definitie van workaholisme meten we dit concept met behulp van twee schalen: excessief werken en compulsief werken. Ons uitgangspunt daarbij wordt gevormd door twee reeds bestaande schalen. Voor het meten van excessief werken wordt de Compulsive Tendencies-schaal van de Work Addiction Risk Test (WART; Robinson, 1999) gebruikt. De naam van deze schaal is enigszins misleidend omdat zeven van de negen items betrekking hebben op hard werken zonder daarbij te verwijzen naar de onderliggende, compulsieve motivatie. Vandaar dat we deze schaal bestaande uit zeven items herbenoemen tot Excessief Werken (EW). De twee overige items verwijzen naar het onvermogen om na werktijd te ontspannen en het zich schuldig voelen wanneer men niet aan het werk is. Een recente Nederlandse studie die met behulp van internet is uitgevoerd, geeft aan dat deze beide items op een aparte factor laden die compulsief werken meet (Schaufeli, Taris \& Bakker, 2006). Voorts bleek uit een Nederlandse studie bij drie onafhankelijke steekproeven dat: (1) de score op de EW-schaal zeer hoog correleert met de totaalscore op de 15 items van de WART en (2) de correlaties van de EW-schaal en de WART met een aantal nevenvariabelen nagenoeg identiek zijn (Taris, Schaufeli \& Verhoeven, 2005). Met andere woorden, de EW-schaal levert praktisch dezelfde informatie op als de complete WART, oftewel de EW-schaal is equivalent met de langere WART.

Voor het meten van compulsief werken wordt de Drive-schaal van de Workaholism Battery (WorkBat; Spence \& Robbins, 1992) gebruikt. Alle acht items van deze schaal hebben betrekking op het dwangmatige karakter van het extreem harde werken van workaholics. Met het oog op onze definitie is deze schaal dan ook herbenoemd tot Compulsief Werken (CW). De interne consistentie van de CW-schaal blijkt voldoende te zijn in steekproeven uit verschillende landen, zoals NieuwZeeland ( $\alpha=.75$, McMillan, Brady, O’Driscoll \& Marsh, 2002), Noorwegen ( $\alpha=.80$, Burke \& Matthiesen, 2004) en Japan $(\alpha=.70$, Kanai, Wakabayashi \& Fling, 1996).

De keuze voor beide bovengenoemde schalen is dus gebaseerd op een gedegen analyse van de grootste gemene deler van de meeste definities van workaholisme. Voor een uitgebreide verantwoording van deze analyse en van de toegevoegde waarde van de combinatie van de EW- en de CW-schaal ten opzichte van andere bestaande schalen (Mudrack \& Naughton, 2001; Robinson, 1999; Spence \& Robbins, 1992) wordt verwezen naar Schaufeli, Taris en Shimazu (2009). 
Inmiddels zijn enkele studies in Nederland uitgevoerd waarin zowel de EW- als de CW-schaal zijn opgenomen als indicatoren van workaholisme. Zo bevestigde de studie van Schaufeli et al. (2006) dat de twee eerder genoemde atypische EWitems laden op de CW-factor in plaats van de EW-factor. Nadat de twee EW-items aan de CW-schaal werden toegevoegd, verbeterde de interne consistentie zowel de EW- als de CW-schaal. Een andere studie onder managers toonde aan dat beide schalen sterk met elkaar samenhangen $(r=.59)$, maar elkaar desalniettemin aanvullen; EW hangt vooral samen met kwantitatieve belasting zoals overwerk en werkdruk, terwijl CW vooral samenhangt met psychische en somatische klachten en gespannen sociale relaties (Schaufeli, Taris \& Van Rhenen, 2008b).

\subsection{De huidige studie}

De huidige studie is bedoeld om een korte, betrouwbare en valide Nederlandse zelfbeoordelingvragenlijst voor workaholisme - de Dutch Workaholisme Scale (DUWAS) - te introduceren als hulpmiddel voor de praktijk. Het eerste doel van het onderzoek is dan ook het ontwikkelen van een korte vragenlijst met een goede factoriële validiteit. Dat wil zeggen, met twee positief samenhangende subschalen - excessief en compulsief werken - waarvan de items niet met elkaar overlappen. Uitgangspunt daarbij zijn de twee reeds bestaande Amerikaanse schalen die hierboven kort zijn besproken. Voor de ontwikkeling van de schaal wordt gebruik gemaakt van een aanzienlijke steekproef uit de Nederlandse beroepsbevolking. Een tweede doel is het normeren van de DUWAS. Dat wil zeggen, het bepalen van statistische afkappunten op basis waarvan workaholisme-scores als '(zeer) laag', 'gemiddeld' dan wel '(zeer) hoog' kunnen worden gekwalificeerd. Het derde doel is het valideren van de beide subschalen van de DUWAS door groepen werknemers die geselecteerd zijn op basis van hun hoge, dan wel lagere score op bovengenoemde schalen te vergelijken op een aantal nevenvariabelen. Omdat workaholisme door ons is gedefinieerd als de combinatie van excessief en compulsief werken willen we aantonen dat diegenen die een hoge score hebben op beide schalen van de DUWAS ('workaholics') het meest ongunstig scoren op een aantal nevenvariabelen in vergelijking tot andere werknemers, die ofwel alleen hard werken, ofwel alleen dwangmatig werken, ofwel noch hard, noch dwangmatig werken. De nevenvariabelen zijn geclusterd rondom de drie thema's: werkomgevingskenmerken, persoonlijkheid en werkuitkomsten.

Werkomgevingskenmerken. Diverse kenmerken van de werkomgeving alsmede van de sociale omgeving buiten het werk zijn in verband gebracht met workaholisme. Daarbij gaat het zowel om potentiële stressoren als om energiebronnen. Zo is de positieve relatie tussen workaholisme en werkdruk in eerder onderzoek aangetoond; werkverslaafden zetten immers zichzelf onder druk door werk op te zoeken (Johnstone \& Johnston, 2005). Het is evident dat het familieleven van een werkverslaafde in het gedrang komt door diens preoccupatie met het werk. Het wekt dan ook geen verbazing dat Bonebright, Clay en Ankenmann (2000) en Taris, Schaufeli en Verhoeven (2005) een positief verband vonden tussen werkverslaving en werk-thuis interferentie. 
Het is voorts aannemelijk dat workaholisme negatief gerelateerd is aan een energiebronnen. Zo kan de fanatieke en streberige werkhouding van workaholics belastend zijn voor diegenen met wie zij samenwerken (Porter, 2001) of samenleven (Bakker, Demerouti \& Burke, 2009; Robinson, 1996). Ten aanzien van collega's kunnen workaholics bijvoorbeeld controlerend zijn (Mudrack \& Naughton, 2001; Porter, 2004). Workaholics zijn bovendien weinig emotioneel betrokken bij hun thuissituatie (Robinson \& Post, 1995). De partners en kinderen van workaholics moeten leven met een fysiek en emotioneel afwezige respectievelijke partner of ouder, hetgeen eenzaamheid en gevoelens van afwijzing (Robinson, 1998c), maar ook de ontwikkeling van psychologische problemen tot gevolg kan hebben (Robinson, 1998a). Workaholics stellen zich bovendien controlerend en perfectionistisch op in de relatie met hun familieleden (Robinson, 1998b). Als gevolg daarvan wordt de sociale steun van anderen op het werk (collega's en leidinggevenden) alsmede in de privésituatie ondermijnd. Uit het bovenstaande volgt:

Hypothese 1: Workaholics scoren het hoogst op de stressoren werkdruk en werkthuis interferentie in vergelijking met andere groepen werknemers.

Hypothese 2: Workaholics scoren het laagst op de energiebronnen sociale steun op het werk (collega's en leidinggevenden) en in de privésituatie (partner, familie en vrienden) in vergelijking met andere groepen werknemers.

Hypothese 3: Workaholics scoren het hoogst op overwerk en werken in het weekend in vergelijking met andere groepen werknemers.

De andere groepen werknemers hebben betrekking op respectievelijk 'harde werkers' (die hoog op EW en laag op CW scoren), 'dwangmatige werkers' (die hoog op CW en laag op EW scoren) en 'niet-werkverslaafden' (die laag op zowel EW als CW scoren). Vanzelfsprekend scoren workaholics zowel hoog op EW als op CW.

Persoonlijkheid. Onderzoek laat zien dat workaholisme gerelateerd is aan neuroticisme (Burke, Matthiesen \& Pallesen, 2006a) en perfectionisme (Clark, Lelchook \& Taylor, 2010; Spence \& Robbins, 1992; Taris, Schaufeli \& Van Beek, 2010). Overigens zijn neuroticisme en perfectionisme - opgevat als een dispositie om alles wat niet perfect is als onacceptabel te beschouwen - onderling nauw met elkaar verwant (Stoeber, Otto \& Dahlbert, 2009). Het is aannemelijk dat het stellen van hoge eisen aan zichzelf, een kenmerk van perfectionisme dat wellicht voortkomt uit een fundamenteel gevoel van angst en onzekerheid (neuroticisme), tot gevolg heeft dat workaholics zo hard en dwangmatig werken. Ook het feit dat workaholics grote moeite hebben met het delegeren van taken naar anderen past in dit beeld (Killinger, 2006).

Hypothese 4: Workaholics scoren het hoogst op neuroticisme en op perfectionisme in vergelijking met andere groepen werknemers.

Werkuitkomsten. Verschillende onderzoeken laten zien dat de componenten van werkverslaving, en dan vooral het compulsieve aspect, negatief gerelateerd zijn aan bijvoorbeeld arbeidstevredenheid (Burke, Matthiesen \& Pallesen, 2006b). Het is bovendien plausibel dat de betrokkenheid bij de organisatie positief samenhangt met workaholisme omdat workaholics gekenmerkt worden door een sterk plichtsbesef en dito verantwoordelijkheidsgevoel met betrekking tot de organisa- 
tie waarvoor ze werken (Scott et al., 1997). Voorts wordt op basis van eerder onderzoek (Burke, 2000) voorspeld dat workaholisme samenhangt met een verminderd welbevinden omdat workaholics zichzelf onvoldoende de kans geven om te herstellen van hun inspanningen, waardoor ze een verhoogde kans lopen op burn-out (Maslach, 1986; Andreassen, Ursin \& Eriksen, 2007). Het tegenovergestelde van burn-out is bevlogenheid, een positieve, affectief-cognitieve toestand van opperste voldoening die wordt gekenmerkt door vitaliteit, toewijding en absorptie (Schaufeli \& Bakker, 2001). Gegeven de positieve relatie met burn-out, wordt verwacht dat workaholisme negatief samenhangt met bevlogenheid (Schaufeli et al., 2008a).

Hypothese 5: Workaholics scoren het laagst op arbeidssatisfactie en het hoogst op organisatiebetrokkenheid in vergelijking met andere groepen werknemers.

Hypothese 6: Workaholics scoren het hoogst op burn-out in vergelijking met andere groepen werknemers.

Hypothese 7: Workaholics scoren het laagst op bevlogenheid in vergelijking met andere groepen werknemers.

\section{Methode}

\subsection{Respondenten}

Voor de ontwikkeling en de normering van de DUWAS, respectievelijk het eerste en tweede doel van het huidige onderzoek, is gebruik gemaakt van een grootschalige steekproef van de Nederlandse beroepsbevolking $(n=11.060)$ van 16 jaar en ouder. De steekproef maakt deel uit van een internationaal databestand dat is samengesteld uit 15 verschillende onderzoeken. De steekproef bestaat voor circa de helft $(45 \%)$ uit vrouwen. De gemiddelde leeftijd is 38 jaar $(s d=10,39)$. Deze beide kenmerken komen globaal overeen met die van de Nederlandse beroepsbevolking (51\% vrouw, gemiddelde leeftijd bevolking 40 jaar, Centraal Bureau voor de Statistiek (CBS, 2009). Circa een derde van de steekproef is werkzaam in de gezondheidszorg en daarmee is deze sector enigszins oververtegenwoordigd. De zakelijke dienstverlening en de communicatiesector omvatten respectievelijk $14 \%$ en $10 \%$ van de steekproef en zijn daarmee enigszins ondervertegenwoordigd.

Voor de verdere validatie door middel van het analyseren van de combinatie van EW en CW, het derde doel van het huidige onderzoek, zijn diegenen uit de eerdergenoemde database geselecteerd $(n=1.166)$ waarvan een score op de dezelfde nevenvariabelen aanwezig was. Deze specifieke onderzoeksgroep omvat drie onafhankelijke steekproeven. Steekproef 1 en 2 bestaan uit werknemers van een Nederlands telecombedrijf (respectievelijk $n=338$ leidinggevenden en $n=455$ werknemers). Steekproef 3 bestaat uit medewerkers van een adviesbureau $(n=373)$. Het onderzoek werd in alle gevallen uitgevoerd in het kader van een werkbelevingsenquête. Het overgrote deel van de geselecteerden was man (78\%). De gemiddelde leeftijd van de werknemers bedroeg 39 jaar $(s d=9,1)$, variërend van 18 tot 62 jaar. 


\subsection{Instrumenten}

- Workaholisme

Workaholisme is gemeten met de schalen Excessief Werken (EW) en Compulsief Werken (CW) (zie tabel 1). De ontwikkeling van beide schalen wordt verderop uitvoerig beschreven. Alle items zijn gescoord op een 4 -puntsschaal ( 1 = 'nooit', 4 = 'altijd').

\section{- Omgevingskenmerken}

Omgevingskenmerken zijn onderverdeeld in potentiële stress- en energiebronnen in navolging van het Job Demands-Resources model (Bakker \& Demerouti, 2007; Schaufeli, Bakker \& Van Rhenen, 2009). Stress- en energiebronnen zijn gemeten met (verkorte) schalen die gebaseerd zijn op de Vragenlijst voor de Beleving en Beoordeling van Arbeid (VBBA; Van Veldhoven, De Jonge, Broersen, Kompier \& Meijman, 2002) die ook in ander onderzoek zijn gebruikt (zie bijvoorbeeld Schaufeli et al., 2008a-b, 2009). Alle items zijn gescoord op een 5-puntsschaal ( 1 = 'nooit', 5 = 'altijd'). De interne consistenties van alle schalen (Cronbach's $\alpha$ ) zijn vermeld in tabel 2.

Stressbronnen zijn gemeten met de schalen Werkdruk (5 items, zoals 'Werkt u onder tijdsdruk?') en Werk-thuis interferentie (7 items, zoals 'Hoe vaak komt het voor dat u moeilijk aan de verplichtingen thuis kunt voldoen omdat $\mathrm{u}$ in gedachten steeds met het werk bezig bent?').

Energiebronnen zijn gemeten met schalen Steun van de leidinggevende (3 items, zoals 'Kunt $u$ als dat nodig is uw directe leidinggevende om hulp vragen?'), Steun van de collega's (3 items, zoals 'Kunt u als dat nodig is collega's om hulp vragen?') en Steun uit de privésituatie ( 3 items, zoals 'Wordt $u$ thuis werk uit handen genomen als u het op het werk drukker heeft?'). Laatstgenoemde schaal is afgeleid van de twee voorgaande schalen.

Overwerk is gemeten door te vragen naar werken in het weekend: 'Hoe vaak werkt u tijdens het weekend?' ( 1 = '(bijna) nooit', 4 = '(bijna) altijd'). Tevens is het percentage overwerk berekend door de overwerkuren te delen door de contracturen en te vermenigvuldigen met 100 . De aldus verkregen overwerkratio, het percentage overwerk per week, bedroeg $20,8 \%(s d=17,3)$. Het gemiddeld aantal contracturen was 38,3 $(s d=3,3$ ) per week en het gemiddelde aantal overuren bedroeg 8,2 $(s d=7,6)$.

\section{- Persoonlijkheid}

Perfectionisme is gemeten met een zelf geconstrueerde schaal (10 items, zoals 'Ik ben niet snel tevreden met het resultaat van mijn werk' en 'Ik haal vaak de laatste foutjes uit het werk van mijn collega's') en wordt gescoord op een 5-puntsschaal ( 1 = 'helemaal mee oneens', 5 = 'helemaal mee eens'). Het persoonlijkheidskenmerk neuroticisme is gemeten met de gelijknamige schaal Neuroticisme (12 items, zoals 'Soms voel ik me volkomen waardeloos') afkomstig uit de Nederlandse versie (Hoekstra, Ormel \& De Fruyt, 1996) van de NEO-Five Factor Inventory (NEO-FFI; Costa \& McCrae, 1992), gebruikmakend van een 5-puntsschaal ( 1 = 'helemaal oneens', 5 = 'helemaal eens'). 


\section{- Werkuitkomsten}

Uitkomsten zijn gemeten met twee zelfgeconstrueerde schalen (zie Schaufeli et al., 2008a-b, 2009) die gebaseerd zijn op de VBBA (Van Veldhoven et al., 2002): Arbeidssatisfactie (3 items, zoals 'Ik ben tevreden met mijn huidige werk') en Organisatiebetrokkenheid (5 items, zoals: 'Ik voel me thuis bij <naam organisatie>'). Alle items zijn gescoord op een 5-puntsschaal ( 1 = 'helemaal mee oneens', 5 = 'helemaal mee eens').

Burn-out is gemeten met twee van de drie subschalen van de Utrechtse Burn-out Schaal (UBOS) (Schaufeli \& Van Dierendonck, 2000), de Nederlandse versie van de Maslach Burnout Inventory-General Survey (Schaufeli, Leiter, Maslach \& Jackson, 1996). De twee kerndimensies zijn Uitputting (5 items, zoals 'Ik voel me mentaal uitgeput door mijn werk') en Distantie (4 items, zoals 'Ik merk dat ik te veel afstand heb gekregen van mijn werk'). Alle items zijn gescoord op een 7-puntsschaal ( 0 = 'nooit', 6 = 'altijd').

Bevlogenheid is gemeten met de Utrechtse Bevlogenheidschaal (UBES, Schaufeli, Salanova, González-Romá \& Bakker, 2002). Dit meetinstrument bestaat uit drie subschalen, te weten Vitaliteit (6 items, zoals 'Op mijn werk bruis ik van energie'), Toewijding (5 items, zoals 'Ik ben trots op het werk dat ik doe') en Absorptie (6 items, zoals 'Ik ga helemaal op in mijn werk'). De items zijn gescoord op een 7-puntsschaal ( 0 = 'nooit', 6 = 'altijd').

\section{Resultaten}

\subsection{De ontwikkeling van de DUWAS}

In verband met mogelijke kanskapitalisatie is de database willekeurig gesplitst in twee steekproeven. De eerste, 'exploratieve' steekproef werd gebruikt om de DUWAS te ontwikkelen ( $n=5.492)$, terwijl de tweede, 'confirmatieve' steekproef werd gebruikt om resultaten te kruisvalideren $(n=5.498)$.

Een exploratieve factoranalyse met behulp van de principale componentenmethode gevolgd door varimaxrotatie over de 8 items van de Excessief Werken (EW)-schaal en de 8 items van de Compulsief Werken (CW)-schaal, leverde drie factoren op met eigenwaarden groter dan één. De totale hoeveelheid verklaarde variantie bedroeg 54,3\%. Alle EW-items met uitzondering van 'Ik voel me schuldig als ik niet aan het werk ben' laadden 0,44 of hoger op de eerste factor. Twee items die hoger dan 0,50 op de eerste factor laadden hadden eveneens een lading hoger dan 0,30 op een van beide andere factoren. De CW-items waren daarentegen verspreid over de tweede en de derde factor, waarbij drie min of meer gelijke dubbelladingen voorkwamen. De hoogste ladingen op de tweede factor hadden te maken met 'zich schuldig voelen' en 'niet kunnen ontspannen', terwijl de hoogste ladingen op de derde factor vooral te maken hadden met een 'sterke drang om te werken'. Na verwijdering van het 'verkeerd' ladende EW-item en de vijf dubbelladingen bleven er 10 items over, 5 voor ieder van de twee schalen. Zoals blijkt uit tabel 1 resulteerde een tweede exploratieve factoranalyse over de 10 overgebleven items in een fraaie simple solution waarbij alle items hoger dan 0,50 laadden op de bedoelde factor (vet gedrukt) en lager dan 0,30 op de andere factor. Op Factor 1 
Tabel 1 Factorladingen van de verkorte Dutch Workaholism Scale (DUWAS) na varimax-rotatie (exploratieve steekproef, $n=5,492$ ).

\begin{tabular}{|c|c|c|c|c|}
\hline Item & & Factor I & Factor 2 & $h^{2}$ \\
\hline $\mathrm{I}$ & Ik heb haast en werk tegen deadlines aan & 0,15 & 0,75 & 0,59 \\
\hline 2 & Ik werk door terwijl mijn collega's al naar huis zijn & 0,24 & 0,62 & 0,44 \\
\hline 3 & $\begin{array}{l}\text { Ik vind het belangrijk om hard te werken, zelfs als ik } \\
\text { eigenlijk geen plezier heb in mijn bezigheden }\end{array}$ & 0,81 & 0,07 & 0,66 \\
\hline 4 & Ik ben druk en heb veel ijzers tegelijk in het vuur & 0,10 & 0,83 & 0,70 \\
\hline 5 & $\begin{array}{l}\text { lk heb het gevoel dat iets in mijzelf me dwingt hard te } \\
\text { werken }\end{array}$ & 0,77 & 0,17 & 0,62 \\
\hline 6 & $\begin{array}{l}\text { Ik besteed meer tijd aan mijn werk dan aan mijn vrien- } \\
\text { den, hobby's, of andere vrijetijdsactiviteiten }\end{array}$ & 0,24 & 0,54 & 0,35 \\
\hline 7 & $\begin{array}{l}\text { Ik voel me verplicht hard te werken, ook al vind ik dat } \\
\text { niet altijd prettig }\end{array}$ & 0,79 & 0,18 & 0,64 \\
\hline 8 & $\begin{array}{l}\text { Ik ben met meerdere dingen tegelijk bezig, ik schrijf } \\
\text { bijvoorbeeld een memo terwijl ik eet en met iemand } \\
\text { telefoneer }\end{array}$ & 0,16 & 0,69 & 0,50 \\
\hline 9 & Ik voel me schuldig als ik vrij neem van mijn werk & 0,61 & 0,25 & 0,44 \\
\hline 10 & $\begin{array}{l}\text { Ik vind het moeilijk om me te ontspannen als ik niet aan } \\
\text { het werk ben }\end{array}$ & 0,55 & 0,29 & 0,40 \\
\hline
\end{tabular}

NB. EW = Excessief werken; CW = Compulsief werken.

laadden alle CW-items en op Factor 2 alle EW-items. De correlatie tussen beide schalen bedroeg 0,49 ( $p<0,001)$. De correlatie van de verkorte $C W$-schaal met de oorspronkelijke schaal was $0,95(p<0,001)$ en die van de verkorte EW-schaal met de oorspronkelijke schaal was 0,92 $(p<0,001)$. Met andere woorden, de verkorte schalen waren nagenoeg identiek aan de oorspronkelijke versies. De waarden van Cronbach's $\alpha$ waren met respectievelijk 0,78 en 0,75 voor CW en EW ruim voldoende (Nunnally \& Bernstein, 1994).

Vervolgens is ter kruisvalidatie in de tweede steekproef een confirmatieve factoranalyse uitgevoerd met behulp van het computerprogramma AMOS (Arbuckle, 2003). Als eerste werd een model getoetst met slechts één latente workaholismefactor waarop alle 10 items laadden, gevolgd door een twee-factormodel met een aparte EW- en CW-factor. Het één-factormodel paste niet goed bij de data $(\chi 2(35)=4135,81 ;$ GFI $=0,84 ;$ AGFI $=0,75 ;$ RMSEA $=0,15 ;$ NFI $=0,75$; CFI $=0,74)$, terwijl de passing van het twee-factormodel goed was $(\chi 2(45)=$ 1471.33; GFI =0,95; AGFI =0,91; RMSEA =0,08; NFI =0,91; CFI =0,91). In het laatste geval voldeden alle passingsmaten aan de daarvoor geldende criteria (zie Byrne, 2009). Beide latente factoren correleerden .54 ( $p<0,001)$. Voorts waren de correlaties tussen de oorspronkelijke en verkorte DUWAS-schalen identiek aan die van de exploratieve steekproef. De waarden van Cronbach's $\alpha$ verschilden met respectievelijk 0,79 en 0,75 voor CW en EW evenmin nauwelijks van die van de andere steekproef. Alles overziend kan geconcludeerd worden dat de kruisvalida- 
tie succesvol verliep; de twee-factorstructuur zoals gevonden in de exploratieve steekproef paste goed bij de gegevens van de confirmatieve steekproef.

\subsection{Samenhang tussen workaholisme en nevenvariabelen}

Ter validatie van beide workaholismeschalen zijn de relaties met een aantal andere nevenvariabelen onderzocht. Ten eerste zijn Pearson product-moment correlaties berekend, waarbij bleek dat alle correlaties in de voorspelde richting waren. Zoals blijkt uit tabel 2 verschilt het patroon van correlaties van EW met dat van CW. EW hangt vooral samen met werkdruk, werk-thuis interferentie en overwerk, terwijl CW vooral samenhangt met neuroticisme, perfectionisme, burnout (uitputting en cynisme) en een geringe mate van bevlogenheid (vitaliteit en toewijding). Met andere woorden, diegenen die excessief hard werken hebben het druk op het werk, werken veel uren en hebben problemen om hun werk te combineren met hun thuissituatie. Diegenen die dwangmatig werken hebben daarentegen meer psychische problemen.

\subsection{Normering}

EW en CW hangen zwak maar in het algemeen significant samen met geslacht $(t(10.983)=-4,39, p<0,001$, respectievelijk $t(10.983)=0,12, p=n s)$ en leeftijd $(r=-0,03, p<.05$, respectievelijk $r=-0,08, p<0,001)$. Op een enkele uitzondering na worden bovendien geen relevante verschillen in workaholisme gevonden tussen beroepsgroepen of sectoren. Een groep die echter opvallend verschilt van de overige groepen is de kleine groep zelfstandige ondernemers $(n=45)$. Zij scoren in vergelijking met de andere beroepsgroepen significant hoger op EW en $C W$, $M=2,88$ respectievelijk $M=2,28$ tegen $M=2,53$ respectievelijk $M=2,00$ $(t(11.058)=3,89, p<0,001$, respectievelijk $t(11.058)=2,86, p<0,001)$. Op grond van het feit dat - met uitzondering van ondernemers - geen of nauwelijks verschillen tussen beroepsgroepen of sectoren zijn gevonden is besloten om een uniforme normering te hanteren zonder daarbij rekening te houden met sekse, leeftijd, beroepsgroep en/of sector.

Op basis van de ruwe scores van de normpopulatie $(n=11.060)$ zijn vijf percentielscores berekend voor de beide schalen van de DUWAS met behulp waarvan een classificatie in vijf categorieën kan worden gemaakt: 'zeer laag' ( $\leq 5$ e percentiel), 'laag' (6 $-25^{\text {ste }}$ percentiel), 'gemiddeld' ( $26^{\text {ste }}-75^{\text {ste }}$ percentiel), 'hoog' (76 $6^{\text {ste }}-94^{\text {ste }}$ percentiel), 'zeer hoog' $\left(\geq 95^{\text {ste }}\right.$ percentiel). Een dergelijke classificatie wordt ook gebruikt bij burn-out (Schaufeli \& Van Dierendonck, 2000) en bevlogenheid (Schaufeli \& Bakker, 2004). In tabel 3 staan de afkapwaarden die behoren bij de percentielscores en die gebruikt kunnen worden voor de classificatie van het niveau van workaholisme.

\subsection{De combinatie van excessief en compulsief werken}

Op basis van de bovenstaande normering kunnen vier groepen worden onderscheiden: (1) 'workaholics' (hoog op zowel EW als CW); (2) 'dwangmatige werkers' (hoog op CW en gemiddeld of (zeer) laag op EW); (3) 'harde werkers'(hoog op EW en gemiddeld of (zeer) laag op CW); (4) 'niet-werkverslaafde werkers' (gemiddeld 


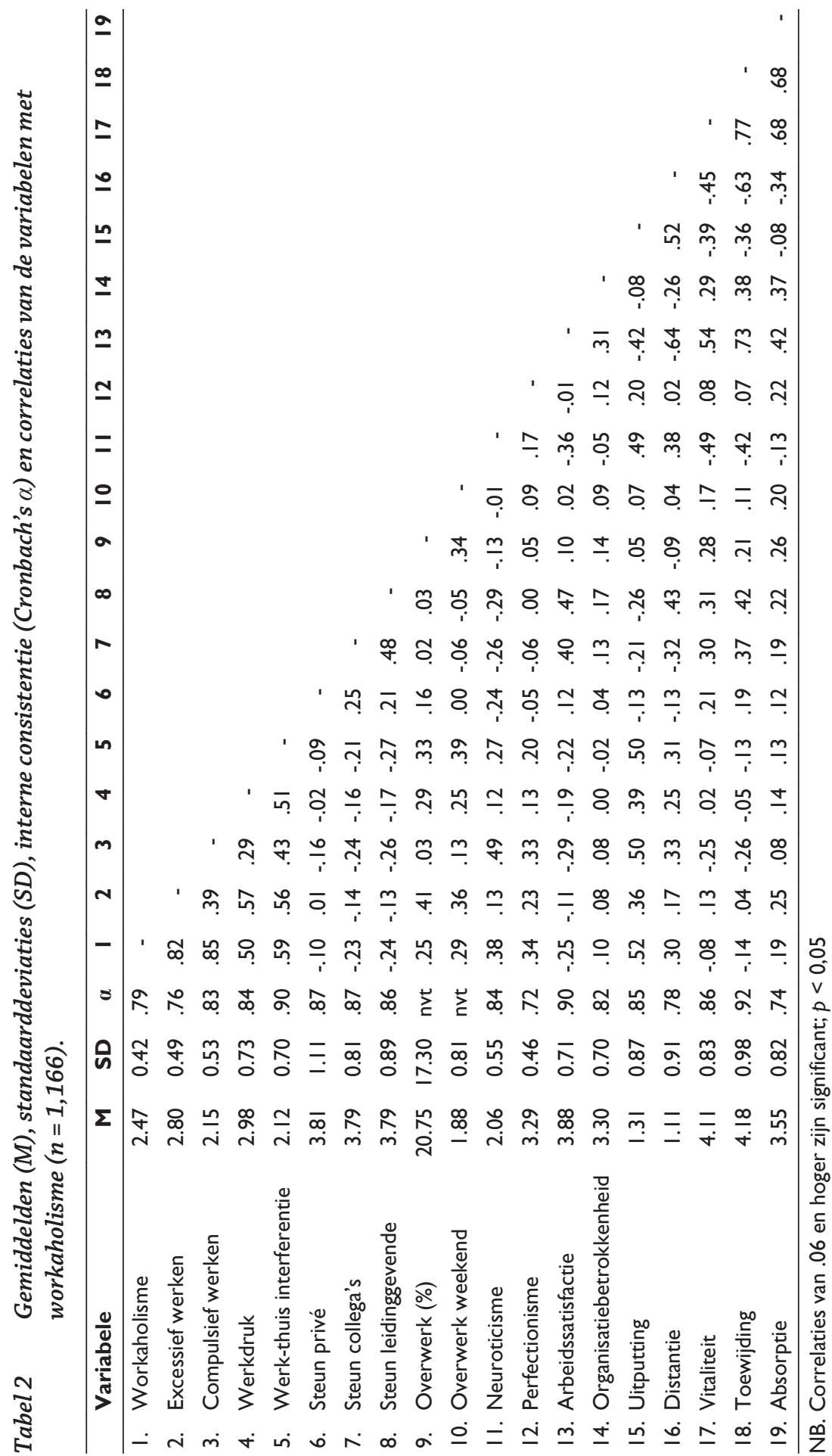


Tabel 3 Gemiddelden (M), standaarddeviaties (SD) en percentielscores ( $p)$ voor Excessief Werken (EW) en Compulsief Werken (CW) $(n=$ 11,060).

\begin{tabular}{lll}
\hline & EW & CW \\
\hline M & 2,53 & $2,0 \mathrm{I}$ \\
SD & 0,60 & 0,64 \\
Zeer laag (p5) & 1,40 & $\mathrm{I}, 00$ \\
Laag (p25) & $1,4 \mathrm{I}-2,00$ & $\mathrm{I}, 0 \mathrm{I}-1,50$ \\
Gemiddeld (p50) & $2,0 \mathrm{I}-2,90$ & $\mathrm{I}, 5 \mathrm{I}-2,40$ \\
Hoog (p75) & $2,9 \mathrm{I}-3,40$ & $2,4 \mathrm{I}-3,00$ \\
Zeer hoog (p95) & $3,4 \mathrm{I}$ & $3,0 \mathrm{I}$ \\
\hline
\end{tabular}

of (zeer) laag op zowel EW als CW). Met behulp van ANOVA's is onderzocht hoe de groepen ten opzichte van elkaar scoren ten aanzien van eerdergenoemde drie domeinen (zie tabel 4). In de onderstaande beschrijving van de resultaten zijn de scores van de 'workaholics' - conform de hypothesen - gecontrasteerd met de scores van de overige drie groepen.

Uit post hoc-analyse blijkt dat juist workaholics zijn blootgesteld aan stressbronnen; ze ervaren meer werkdruk en werk-thuis interferentie dan de drie overige groepen (Hypothese 1 bevestigd). Ook beschikken workaholics over minder energiebronnen dan harde werkers (steun vanuit de privésituatie, van collega's en de leidinggevende) en niet-werkverslaafde werkers (steun van collega's en de leidinggevende). Ze verschillen echter niet van dwangmatige werknemers in de mate van ervaren steun (Hypothese 2 deels bevestigd). Verder maken workaholics meer overuren en werken ze vaker in het weekend dan dwangmatige werkers en nietwerkverslaafde werkers (Hypothese 3 deels bevestigd). Met betrekking tot persoonlijkheid (neuroticisme en perfectionisme) scoren workaholics ongunstiger dan de harde werkers en niet-werkverslaafden, maar gunstiger dan dwangmatige werkers (Hypothese 4 deels bevestigd). Ten aanzien van werkuitkomsten scoren workaholics op arbeidssatisfactie in verhouding tot harde werkers en niet-werkverslaafde werknemers laag. Workaholics verschillen echter niet van de andere groepen ten aanzien van hun betrokkenheid bij de organisatie (Hypothese 5 deels bevestigd). Workaholics voelen zich in vergelijking met de overige drie groepen het meest uitgeput en ze scoren hoger op distantie dan de harde werkers en nietwerkverslaafde werknemers. Met andere woorden: workaholics hebben relatief veel burn-outklachten (Hypothese 6 grotendeels bevestigd). Ofschoon workaholics lager scoren op vitaliteit dan harde werkers, voelen ze zich energieker dan dwangmatige werkers. Ze scoren lager op toewijding dan harde werkers en nietwerkverslaafde werkers, maar niet lager dan dwangmatige werkers. Tot slot voelen ze zich vaker geabsorbeerd door hun werk dan dwangmatige werkers en nietwerkverslaafde werkers, maar niet vaker dan harde werkers (Hypothese 7 deels bevestigd). Kort samengevat scoren werkverslaafden over het algemeen ongunstiger op omgevingskenmerken, persoonlijkheid en uitkomsten in vergelijking met 
de overige drie groepen. Echter, in sommige gevallen zijn de scores van met name de dwangmatige werkers, vergelijkbaar of zelfs wat ongunstiger dan die van werkverslaafde werkers.

\section{Discussie}

In dit onderzoek is een nieuw Nederlandstalig instrument om workaholisme te meten geïntroduceerd; de DUtch WorkAholism Scale (DUWAS). Op basis van de gegevens van ruim 11.000 Nederlandse werknemers werd duidelijk dat werkverslaving betrouwbaar gemeten kan worden met twee relatief korte schalen van vijf items Excessief Werken (EW) en Compulsief Werken (CW). Beide schalen overlappen elkaar gedeeltelijk, dat wil zeggen hun gedeelde variantie is ongeveer $30 \%$. Het feit dat het bij workaholisme gaat om de combinatie van excessief werken (de gedragsmatige component) en compulsief werken (de cognitieve component) wordt empirisch onderstreept doordat diegenen die hoog scoren op beide schalen van de DUWAS, blootstaan aan de meest ongunstige omgevingskenmerken, de meest problematische persoonlijkheid hebben en de slechtste uitkomsten rapporteren. Met andere woorden, er kan dus geconcludeerd worden dat de DUWAS op betrouwbare en valide wijze de tweedimensionele omschrijving van workaholisme weerspiegelt, zoals deze elders is geformuleerd (Taris, Schaufeli \& Shimazu, 2010; Schaufeli, Taris \& Bakker, 2008a). De meerwaarde van de huidige studie ten opzichte van eerdergenoemde artikelen ligt in de ontwikkeling van normscores, welke een handvat kunnen bieden voor bedrijfsartsen en A\&O-psychologen om workaholisme te onderscheiden. Het nut van de normscores wordt geillustreerd door de bevinding dat werknemers met een combinatie van hoge scores op excessief en compulsief werken over het algemeen ongunstigere uitkomsten ervaren dan werknemers met sec hoge scores op excessief dan wel compulsief werken.

Er zijn echter ook enkele onverwachte resultaten gevonden die om nadere beschouwing vragen. Zo blijkt Hypothese 1 over de relatie tussen workaholisme en stressoren wel ondersteund te worden, maar Hypothese 2 over de relatie tussen workaholisme en energiebronnen slechts gedeeltelijk. Het opmerkelijke daarbij is dat workaholics niet verschillen van 'dwangmatige werkers' in ervaren steun vanuit hun omgeving. Workaholics verschillen ook niet van dwangmatige werkers in hun mate van perfectionisme en neuroticisme (Hypothese 4), arbeidssatisfactie (Hypothese 5), distantie (Hypothese 6) en toewijding (Hypothese 7) ten opzichte van hun werk. Bovendien scoren dwangmatige werkers zelfs ongunstiger dan workaholics op vitaliteit en absorptie (Hypothese 7). Blijkbaar hebben beide typen werknemers een enigszins overeenkomstig profiel wat betreft persoonlijkheidskenmerken en uitkomsten. Dit is niet verwonderlijk aangezien het compulsieve element de meest centrale en nadelige component is van workaholisme (Schaufeli et al., 2008a-b).

Het feit dat workaholics in verhouding hoog scoren op absorptie is ook niet opzienbarend omdat workaholisme gekarakteriseerd wordt door het zich volledig onderdompelen in het werk (Porter, 1996) en door het onvermogen om het werk 


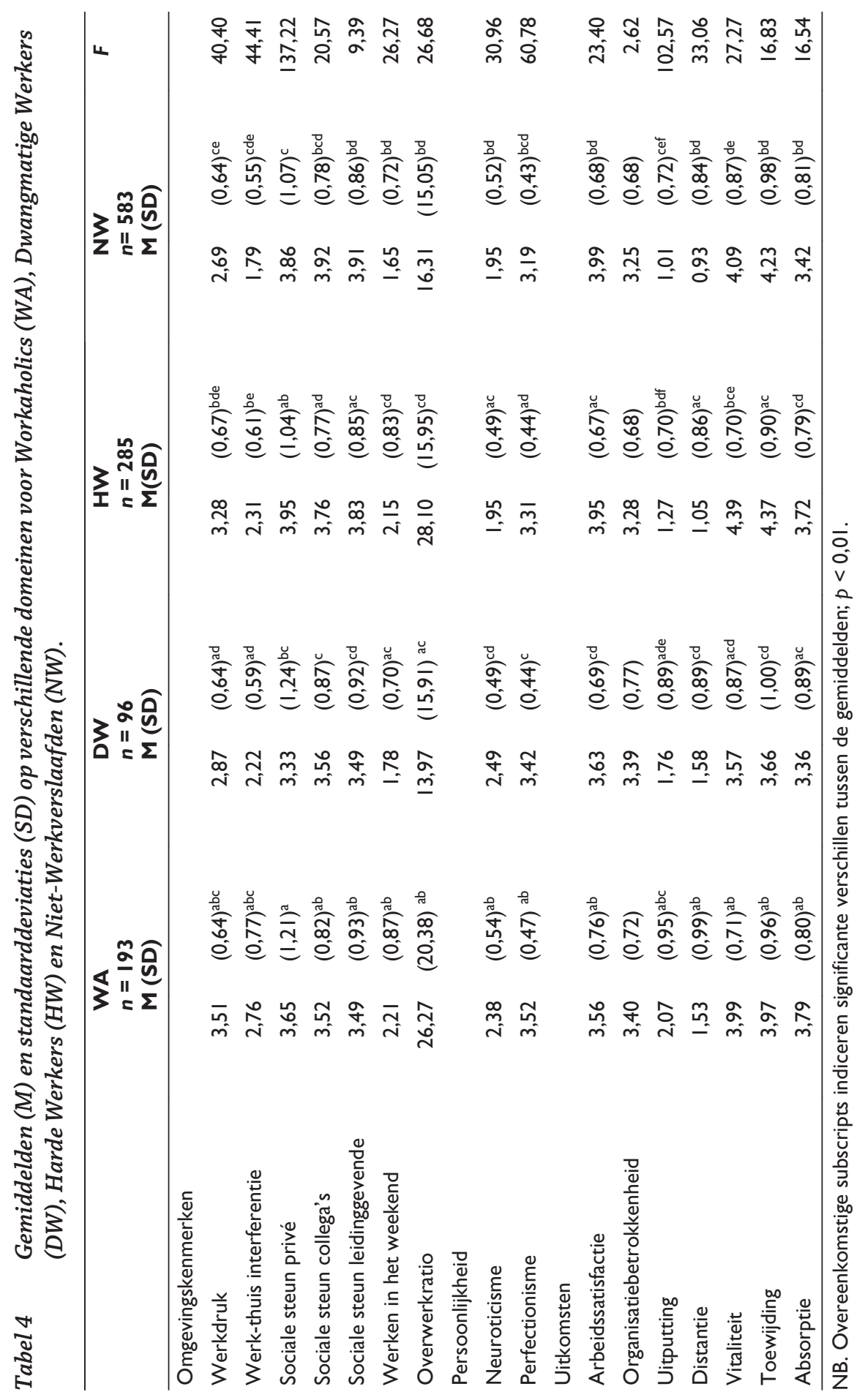


los te laten (McMillan et al., 2001). Een dergelijke omschrijving overlapt sterk met die van absorptie als '...being fully concentrated and deeply engrossed in one's work, whereby time passes quickly and one has difficulties with detaching oneself from work' (Schaufeli et al., 2002, p. 75). Met andere woorden, workaholisme en bevlogenheid overlappen elkaar voor wat betreft het geheel en al opgaan in het werk (absorptie). Echter, op basis van de Self-Determination Theory (Gagné \& Deci, 2005) kan vermoed worden dat de onderliggende motivatie fundamenteel verschilt: bij bevlogenheid is er sprake van intrinsieke motivatie, terwijl er bij workaholisme sprake is van gecontroleerde, geïntrojecteerde motivatie (Van Beek, Taris \& Schaufeli, 2010). Het laatste verwijst naar een motivationele regulatiemodus waarbij taak-extrinsieke elementen zoals behoud van zelfwaarde en sociale erkenning zijn geïnternaliseerd en het werkgedrag sturen (Koestner \& Losier, 2004). Oftewel, er is dus sprake van plezier tegenover innerlijke dwang om te werken.

Het gegeven dat workaholics vitaler zijn dan dwangmatige werknemers is minder inzichtelijk. Men zou kunnen veronderstellen dat een bepaalde mate van vitaliteit een voorwaarde is om hard te kunnen werken. Dwangmatige werkers hebben wel de drang, maar niet de energie om hard te werken. Echter, workaholics ervaren wel meer uitputting dan de overige groepen, waaronder dwangmatige werkers. Dit zou kunnen betekenen dat voor dwangmatige werkers de lage mate van vitaliteit een beschermende factor zou kunnen zijn voor burn-out; hun lage energieniveau voorkomt dat ze gehoor geven aan hun dwang om hard te werken. Over de relatie tussen bevlogenheid, burn-out en workaholisme is echter nog te weinig bekend om goed onderbouwde uitspraken te kunnen doen.

Een andere opvallende bevinding is dat Hypothese 3, waarin werd gesteld dat workaholics de meeste overuren maken, slechts deels wordt bevestigd. Harde werkers verschillen namelijk niet van workaholics in het aantal uren overwerk. Bij nader inzien is dit niet verwonderlijk, omdat wanneer iemand excessief werkt het niet direct hoeft te suggereren dat diegene werkverslaafd is. Men kan hard werken om veel verschillende redenen. Eén daarvan is dat een werknemer heel bevlogen kan zijn in zijn of haar werk (Schaufeli et al., 2006). Het resultaat dat de groep harde werkers een hoge mate van vitaliteit rapporteert, onderstreept de redenering dat sommige werkers hard werken, omdat ze zich energiek voelen en zin hebben om aan het werk te zijn, zonder daarbij werkverslaafd te zijn.

Tot slot is het opmerkelijk dat workaholics ten aanzien van hun betrokkenheid bij de organisatie niet verschillen van de overige groepen. Blijkbaar voelen de workaholics zich niet in sterkere mate 'een deel' van de organisatie dan dat andere werkers dat doen. Voor workaholics is wellicht vooral hard werken belangrijk en tot op een bepaalde hoogte maakt het niet uit voor welke organisatie ze dat doen.

\subsection{Beperkingen van de studie}

Een evidente beperking is het feit dat uitsluitend zelfrapportages zijn gebruikt. Een interessante optie zou in dit verband zijn om de oordelen van anderen zoals collega's, leidinggevenden en partners te relateren aan de scores op de DUWAS. 
Burke en Ng (2007) vonden correlaties tussen zelfrapportage op de WorkBat (Spence \& Robbins, 1972) en beoordeling door collega's die varieerden van 0,26 tot 0,57 , al naar gelang de workaholisme-dimensie. Ten slotte zijn er geen instrumenten opgenomen die soortgelijke begrippen als workaholisme meten zoals 'obsessive passion' (Vallerand, Blanchard et al., 2003), 'overcommitment' (Siegrist, 1998) en Type A-persoonlijkheid (Day \& Jreige, 2002). Hierdoor was het niet mogelijk om de convergente validiteit van de DUWAS vast te stellen. Ten slotte, perfectionisme is gemeten als een eendimensionaal construct. Uit onderzoek blijkt echter dat perfectionisme uit een adaptieve en maladaptieve dimensie bestaat, respectievelijk een hoge standaard voor jezelf hebben en bang zijn om fouten te maken (Frost, Marten, Lahart \& Rosenblate, 1990). Daarbij rijst de vraag hoe deze dimensies van perfectionisme op verschillende wijze samenhangen met workaholisme. Een duidelijker onderscheid tussen deze vormen van perfectionisme biedt een beter inzicht in de risicofactoren voor workaholisme. Taris, Van Beek en Schaufeli (2010), toonden recentelijk aan dat workaholisme met name samengaat met het maladaptieve element van perfectionisme en niet met de adaptieve component van perfectionisme.

\subsection{Implicaties}

De resultaten van ons onderzoek impliceren dat met de DUWAS op betrouwbare en valide wijze onderzoek kan worden gedaan naar werkverslaving in Nederland. Het huidige onderzoek laat bovendien zien dat de combinatie van excessief en compulsief werken ogenschijnlijk ongunstige gevolgen heeft. De huidige studie biedt verschillende handvatten om het werkverslavingsprobleem aan te pakken. Enerzijds leent de DUWAS zich vanwege haar theoretische verankering voor wetenschappelijk onderzoek naar oorzaken en gevolgen van workaholisme en naar relaties met andere, soortgelijke begrippen (Schaufeli et al., 2009).

Anderzijds kan de DUWAS in de praktijk worden ingezet als screeningsinstrument om werkverslavingsproblematiek tijdig te identificeren. De normgegevens kunnen bijvoorbeeld door arbodiensten in het kader van een Preventief Medisch Onderzoek (PMO) gebruikt worden om specifieke 'risicogevallen' op te sporen en de betreffende werknemers een geschikt advies te geven voor een vervolgtraject. Vroegtijdige signalering is van belang omdat het kan bijdragen aan een effectieve preventiebehandeling van workaholisme (Van Wijhe, Schaufeli \& Peeters, 2010). Meer gedetailleerd onderzoek naar de sensitiviteit en de specificiteit van de DUWAS is echter wenselijk, met name met het oog op toepassing van de DUWAS voor individuele diagnostiek.

Voorts kan met behulp van de normscores het aantal werkverslaafden worden vastgesteld in teams, afdelingen, functiegroepen of in organisaties als geheel, bijvoorbeeld in het kader van een werkbelevingsonderzoek. Door de DUWAS op te nemen in zo'n doorgaans periodiek onderzoek, kan gericht HRM-beleid worden gevoerd om werkverslaving te voorkomen. Immers, zoals uit ons onderzoek blijkt kan een organisatie maar beter niet te veel werkverslaafden hebben; ze zijn minder tevreden over hun werk, ervaren ze meer burn-outklachten en zijn ze minder 
bevlogen dan hun niet-werkverslaafde collega's. Het is dus van belang dat managers en andere leidinggevenden op de hoogte zijn van de mate waarin hun werknemers werkverslaafd zijn. De DUWAS kan daarbij dus worden ingezet.

Ten slotte kan de DUWAS, behalve als screeningsinstrument, ook gebruikt worden om het effect van interventies voor workaholisme te evalueren. Zo loopt er momenteel een onderzoek naar het effect van een e-coachingsmodule die door werknemers met (dreigende) werkverslavingsproblematiek gevolgd kan worden, en waarbij de DUWAS als criteriummaat wordt gebruikt.

Kortom, met de DUWAS beschikken we over een betrouwbaar en valide instrument dat zowel in de wetenschap als in de praktijk kan worden gebruikt om werkverslaving te meten.

\section{Praktijkbox}

Wat betekenen de resultaten voor de praktijk? Hoe te werken aan de screening en preventie van werkverslaving?

Werkverslaving bestaat uit een combinatie van hard werken en dwangmatig werken. Hardwerkende werknemers zijn dus op zichzelf geen reden tot zorg, maar wanneer werknemers ook dwangmatig werken kan dit negatieve effecten hebben.

- De DUWAS kan als screeningsinstrument voor werkverslaving worden gebruikt, bijvoorbeeld bij Preventief Medisch Onderzoek (PMO) in het kader van de Arbowet. Aldus kan de DUWAS bijdragen aan de vroegtijdige ontdekking of er sprake is van (een risico op) werkverslaving, hetgeen interventie vergemakkelijkt.

- Op basis van normscores kan de ernst van de werkverslavingsproblematiek in kaart worden gebracht. Met name wanneer een werknemer zeer hoog op beide schalen van de DUWAS scoort, is de kans op nadelige consequenties het grootst.

- De DUWAS kan worden ingezet voor evaluatie en effectmeting ten behoeve van interventies. Dit draagt bij aan een kwaliteitsverbetering van interventies, maar ook inzicht in de veranderbaarheid van werkverslaafd gedrag.

- Door de DUWAS op te nemen in werkbelevingsonderzoek kan gericht HRM-beleid gevoerd worden met het doel om werkverslaving te voorkomen.

\section{Summary}

Workaholism

Work addiction or workaholism is defined as the uncontrollable need to work excessively hard. Based on this definition, the DUWAS (Dutch Workaholism Scale) is introduced, a brief two-dimensional self-report instrument that includes two correlated subscales of five items each: Working Excessively (WE) and Working Compulsively (WC). Using a national Dutch database $(n=11.060)$ cut-off scores were computed that allow a classification of levels of workaholism. Analy- 
ses $(n=1.166)$ reveal that particularly the combination of high scores on both WE and CW is unfavorable. It is concluded that the DUWAS is a reliable and valid inventory that can, for instance, be used as a screening tool to identify workaholic employees.

Keywords: workaholism, validation, screening instrument, cut off

\section{Literatuur}

Andreassen, C.S., Ursin, H., \& Eriksen, H.R. (2007). The relationship between strong motivation to work, 'workaholism', and health. Psychology and Health, 22, 615-629.

Arbuckle, J.L. (2003). AMOS 5.0 (Computer Software). Chicago: SPSS.

Bakker, A.B. \& Demerouti, E. (2007). The Job Demands-Resources model: State of the art. Journal of Managerial Psychology, 22, 309-328.

Bakker, A.B., Demerouti, E., \& Burke, R. (2009). Workaholism and relationship quality: A spillover-crossover perspective. Journal of Occupational Health Psychology, 14, 23-33.

Bonebright, C.A., Clay, D.L., \& Ankenmann, R.D. (2000). The relationship of workaholism with work-life conflict, life satisfaction, and purpose in life. Journal of Counseling Psychology, 47, 469-477.

Burke, R. (2000). Workaholism in organizations: Psychological and physical well-being consequences. Stress and Health, 16, 11-16.

Burke, R.J. \& Koksal, H. (2002). Workaholism among a sample of Turkish managers and professionals: An exploratory study. Psychological Reports, 91, 60-68.

Burke, R.J. \& Matthiesen S.B. (2004). Workaholism among Norwegian journalists: Antecedents and consequences. Stress \& Health, 20, 301-308.

Burke, R.J. \& Ng, E.S.W. (2007). Workaholic behaviors: Do colleagues agree? International Journal of Stress Management, 14, 312-320.

Burke, R.J., Matthiesen, S.B., \& Pallesen, S. (2006a). Personality correlates of workaholism. Personality and Individual Differences, 40, 1223-1233.

Burke, R.J., Matthiesen, S.B., \& Pallesen, S. (2006b). Workaholism, organizational life and well-being of Norwegian nursing staff. Career Development International, 11, 463-477.

Burke, R.J., Richardsen, A.M., \& Martinussen, M. (2002). Psychometric properties of. Spence and Robbins' measures of workaholism components. Psychological Reports, 91, 1098-1104.

Byrne, B. (2009). Structural equation modeling with AMOS: Basic concepts, applications, and programming (2de editie). Hillsdale (NJ): Lawrence Erlbaum Associates.

CBS (2009). Bevolking; kerncijfers naar diverse kenmerken. Centraal Bureau voor de Statistiek. Gedownload op 6 januari 2009 van http://statline.cbs.nl/

Clark, M.A., Lelchook, A.M., \& Taylor, M.L. (2010). Beyond the Big Five: How narcissism, perfectionism, and dispositional affect relate to workaholism. Personality and Individual Differences, 48, 786-791.

Costa, P.T. \& McCrae, R.R. (1992). NEO-PI-R Professional Manual. Odessa (FL): Psychological Assessment Resources.

Day, A.L. \& Jreige, S. (2002). Examining Type A behavior pattern to explain the relationship between job stressors and psychosocial outcomes. Journal of Occupational Health Psychology, 7, 109-120.

De Vos, E. (2003). Workaholisme: De kick van een 80-urige werkweek. Intermediair, 17 april, 12-17. 
Frost, O., Marten, P., Lahart, C., \& Rosenblate, R. (1990). The dimensions of perfectionism. Cognitive Therapy and Research, 14, 449-468.

Gagné, M. \& Deci, E.L. (2005) Self-determination theory and work motivation. Journal of Organizational Behavior, 26, 331-362.

Hoekstra, H.A., Ormel, J., \& De Fruyt, F. (1996). Handleiding NEO Persoonlijkheids-vragenlijsten NEO-PI- R en NEO-FFI. Lisse: Swets \& Zeitlinger.

Johnstone, A. \& Johnston, L. (2005). The relationship between organizational climate, occupational type, and workaholism. New Zealand Journal of Psychology, 34, 181-188.

Kanai, A., Wakabayashi, M., \& Fling, S. (1996). Workaholism among employees in Japanese corporations: An examination based on the Japanese version of the Workaholism Scales. Japanese Psychological Research, 38, 192-203.

Killinger, B. (2006). The workaholic breakdown syndrome. In R.J. Burke (Ed.), Research companion to working time and work addiction (pp. 61-88). Cheltenham (UK): Edward Elgar.

Koestner, R. \& Losier, G.F. (2004). Distinguishing three ways of being highly motivated: A closer look at introjection, identification, and intrinsic motivation. In E.L. Deci \& R.M. Ryan (Eds.), Handbook of self-determination research (pp. 101-122). Rochester (NY): University of Rochester Press.

Machlowitz, M. (1980). Workaholics. Living with them, working with them. Reading (MA): Addison-Wesley.

Maslach, C. (1986). Stress, burnout and workaholism. In R.R. Killberg, P.E. Nathan, \& R.W. Thoreson (red.), Professionals in distress: Issues, syndromes and solutions in psychology (pp. 53-73). Washington (DC): American Psychological Association.

McMillan, L.H.W. \& O’Driscoll, M.P. (2006). Exploring new frontiers to generate an integrated definition of workaholism. In R. Burke (red.), Research companion to working time and work addiction (pp. 89-107). Cheltenham (UK): Edward Elgar.

McMillan, L.H.W., Brady, E.C., O’Driscoll, M.P., \& Marsh, N. (2002). A multifaceted validation study of Spence and Robbins' (1992) Workaholism Battery. Journal of Occupational and Organizational Psychology, 75, 357-368.

McMillan, L.H.W., O’Driscoll, M.P., Marsh, N.V., \& Brady, E.C. (2001). Understanding workaholism: Data synthesis, theoretical critique, and future design strategies. International Journal of Stress Management, 8, 69-91.

Mudrack, P.E. (2004). Job involvement, obsessive-compulsive personality traits, and workaholic behavioral tendencies. Journal of Organizational Change Management, 7, 490-508.

Mudrack, P.E. \& Naughton, T.J. (2001). The assessment of workaholism as behavioral tendencies: Scale development and preliminary empirical testing. International Journal of Stress Management, 8, 93-111.

Ng, T.W.H., Sorensen, K.L., \& Feldman, D.C. (2007). Dimensions, antecedents, and consequences of workaholism: a conceptual integration and extension. Journal of Organizational Behavior, 28, 111-136.

Nunnally, J.C. \& Bernstein, I.H. (1994). Psychometric theory (3de editie). New York: McGraw-Hill.

Oates, W. (1968). On being a 'workaholic' (a serious jest). Pastoral Psychology, 19, 16-20.

Oates, W. (1971). Confessions of a workaholic: The facts about work addiction. New York: World Publishing Company.

Porter, G. (1996). Organizational impact of workaholism: Suggestions for researching the negative outcomes of excessive work. Journal of Occupational Health Psychology, 1, 70-84. 
Porter, G. (2001). Workaholic tendencies and the high potential for stress among co-workers. International Journal of Stress Management, 8, 147-164.

Porter, G. (2004). Work, work ethic, work excess. Journal of Organizational Change Management, 17, 424-439.

Robinson, B.E. (1996). The relationship between work addiction and family functioning: Clinical implications for marriage and family therapists. Journal of Family Psychotherapy, 7, 13-39.

Robinson, B.E. (1998a). Chained to the desk: a guidebook for workaholics, their partners and children, and the clinicians who treat them. New York: New York University Press.

Robinson, B.E. (1998b). Spouses of workaholics: Clinical implications for psychotherapy. Psychotherapy, 35, 260-268.

Robinson, B.E. (1998c). The workaholic family: A clinical perspective. American Journal of Family Therapy, 26, 63-73.

Robinson, B.E. (1999). The Work Addiction Risk Test: Development of a tentative measure of workaholism. Perceptual and Motor Skills, 88, 199-210.

Schaufeli, W. \& Bakker, A. (2001). Werk en welbevinding. Naar een positieve benadering in de arbeids- en gezondheidspsychologie. Gedrag \& Organisatie, 5, 229-253.

Schaufeli, W.B. \& Bakker, A.B. (2004). Bevlogenheid: Een begrip gemeten. Gedrag \& Organisatie, 17, 89-112.

Schaufeli, W.B., Bakker, A.B., \& Van Rhenen, W. (2009). How changes in job demands and resources predict burnout, work engagement, and sickness absenteeism. Journal of Organizational Behavior, 30, 893-917.

Schaufeli, W.B. \& Van Dierendonck, D. (2000). Handleiding van de Utrechtse Burnout Schaal (UBOS). Lisse: Swets \& Zeitlinger.

Schaufeli, W.B., Taris, T.W., \& Bakker, A. (2006). Dr. Jekyll and Mr. Hyde: On the differences between work engagement and workaholism. In R. Burke (red.), Work hours and work addiction (pp. 193-252). Northhampton (UK): Edward Elgar.

Schaufeli, W.B., Taris, T.W., \& Bakker, A.B. (2008a). It takes two to tango: Workaholism is working excessively and working compulsively. In R.J. Burke \& C.L. Cooper (red.), The long work hours culture: Causes, consequences and choices (pp. 203-226). Bingley, (UK): Emerald.

Schaufeli, W.B., Taris, T.W., \& Van Rhenen, W. (2008b). Workaholism, burnout and engagement: Three of a kind or three different kinds of employee well-being. Applied Psychology: An International Review, 57, 173-203.

Schaufeli, W.B., Shimazu, A., \& Taris, T.W. (2009). Being driven to work excessively hard. The evaluation of a two-factor measure of workaholism in the Netherlands and Japan. Cross-Cultural Research, 43, 320-348.

Schaufeli, W.B., Leiter, M.P., Maslach, C., \& Jackson, S.E. (1996). Maslach burnout inventory - general survey. In C. Maslach, S.E. Jackson \& M.P. Leiter (red.), The Maslach burnout inventory: Test manual (3rd ed., p. 22-26). Palo Alto: Consulting Psychologists Press.

Schaufeli, W.B., Salanova, M., González-Romá, V., \& Bakker, A.B (2002). The measurement of engagement and burnout: A two sample confirmatory factor analytic approach. Journal of Happiness Studies, 3, 71-92.

Scott, K.S., Moore, K.S., \& Miceli, M.P. (1997). An exploration of the meaning and consequences of workaholism. Human Relations, 50, 287-314.

Siegrist, J. (1998). Adverse health effects of effort-reward imbalance at work. In C.L. Cooper (red.), Theories of organizational stress (pp. 190-204). Oxford (UK): Oxford University Press. 
Snir, R. \& Zohar, D. (2008). Workaholism as discretionary time investment at work: An experience-sampling study. Applied Psychology: An International Review, 57, 109-127.

Spence, J.T. \& Robbins, A.S. (1992). Workaholism: Definition, measurement, and preliminary results. Journal of Personality Assessment, 58, 160-178.

Stoeber, J., Otto, K., \& Dalbert, C. (2009). Perfectionism and the big five: Conscientiousness predicts longitudinal increases in self-oriented perfectionism. Personality and Individual Differences, 47, 363-368.

Taris, T.W. \& Schaufeli, W.B. (2007). Workaholisme. In W.B. Schaufeli \& A.B. Bakker (red.), De psychologie van arbeid en gezondheid (pp. 359-372). Houten: Bohn Stafleu Van Loghum.

Taris, T.W., Van Beek, I., \& Schaufeli, W.B. (2010). Perfectionism, workaholism, and burnout: A mediational analysis. Romanian Journal of Applied Psychology, 12, 1-7.

Taris, T.W., Schaufeli, W.B., \& Shimazu, A. (2010). The push and pull of work: About the difference between workaholism and work engagement. In A.B. Bakker \& M.P. Leiter (red.), Work engagement: A handbook of essential theory and research (pp. 39-53). New York: Routledge.

Taris, T.W., Schaufeli, W.B., \& Verhoeven, L.C. (2005). Internal and external validation of the Dutch Work Addiction Risk Test: Implications for jobs and non-work conflict. Journal of Applied Psychology: An international Review, 54, 37-60.

Taris, T.W., Geurts, S.A.E., Schaufeli, W.B., Blonk, R.W.B., \& Lagerveld, S. (2008). All day and all of the night: The relative contribution of two dimensions of workaholism to well-being in self-employed workers. Work \& Stress, 22, 153-165.

Unwin, T. (2004). Gustave Flaubert, the hermit of Croisset. In T. Unwin (red.), The Cambridge companion to Flaubert (pp. 1-24). Cambridge (UK): Cambridge University Press.

Vallerand,R.J., Blanchard, C.M., Mageau, G.A., Koestner, R., Ratelle, C., Leonard, M., \& Gagné, M. (2003). Les passions de l'âme: On obsessive and harmonious passion. Journal of Personality and Social Psychology, 85, 756-767.

Van Beek, I., Taris, T.W., \& Schaufeli, W.B. (2010). Motivation and job related well-being: Why do workaholic, engaged and burned-out employees work so hard. Manuscript aangeboden ter publicatie.

Van Veldhoven, M., De Jonge, J., Broersen, S., Kompier, M., \& Meijman, T. (2002). Specific relationships between psychosocial job conditions and job-related stress: A three-level analytic approach. Work \& Stress, 16, 207-228.

Van Wijhe, C., Schaufeli, W.B. \& Peeters, M.C.W. (2010). Understanding and treating workaholism: Setting the stage for successful interventions. In: R.J. Burke \& C. Cooper (red.), Risky Business: Psychological, physical and financial costs of high risk behaviour in organizations (pp. 107-134). Farnham: Ashgate. 